\title{
The Role of Science in Regulating Sustainable Energy Democracy
}

\author{
Seita Romppanen
}

In order for sustainability to be realized, the clean energy transition needs to be closely informed by science. The measures chosen to promote the sustainable energy transition are essentially linked to questions of science: what proportion of $\mathrm{CO}_{2}$ in the atmosphere should we be pursuing? Within what timeframe is it still possible for us to change course to avoid the catastrophic consequences of climate change? What is the potential and feasibility of the different renewable energy technologies to which we are shifting ${ }^{1}{ }^{1}$ The challenge of decarbonization brings forward a distinct science and lawmaking interface that underlines the importance of contributions from both disciplines. The regulatory processes driving the sustainable energy transition necessitate active and inclusive dialogue between the scientific and lawmaking communities. Sustainable energy transition is hence fundamentally a science-based quest that requires science and lawmaking to mingle. ${ }^{2}$

The notion of science also establishes an interesting new space in which to explore the yet nascent concept of energy democracy. ${ }^{3}$ Furthermore, analysing the sustainable energy transition through the science and lawmaking 4

1 James Angel, Strategies of Energy Democracy (Rosa Luxemburg Stiftung 2016) 7 .

2 See e.g. Andreas Fischlin and Maria Ivanova, 'Introduction. Scientific and Political Drivers for the Paris Agreement' in Daniel Klein and others (eds), The Paris Agreement on Climate Change: Analysis and Commentary (oup 2017) 3-8, 3; J B Ruhl, 'Reconstructing the Wall of Virtue: Maxims for the Co-Evolution of Environmental Law and Environmental Science' (2007) 37(4) Environmental Law Review 1063-1082, 1074.

3 Kacper Szulecki, 'Conceptualizing energy democracy' (2018) 27(1) Environmental Politics 21-41, 21-22; Matthew J Burke and Jennie C Stephens, 'Energy democracy: Goals and policy instruments for sociotechnical transitions' (2017) 33 Energy Research \& Social Science 35-48, 35; Bregje Van Veelen and Dan van der Horst, 'What is energy democracy? Connecting social science energy research and political theory' (2018) 46 Energy Research \& Social Science $19-28,20$.

4 Science and law establish a two-way relationship. Science is 'imported' into law to 'guide and illuminate policy', and at the same time, law 'exports' its problems to be solved by scientific

(C) SEITA ROMPPANEN, 2021 | DOI:10.1163/9789004465442_004

This is an open access chapter distributed under the terms of the CC BY-NC 4.0 Lieentse. Romppanen - 9789004465442 Downloaded from Brili. come4/25/2023 11:20:49PM 
nexus is useful in terms of building the argument that energy democracy is a legal objective. For this purpose, this chapter engages with the two underlying pillars of sustainable energy democracy promoted by this book - sustainability and energy justice - the latter with a focus on procedural justice. ${ }^{5}$ The chapter makes the case for science playing a key role in energy democracy from two stances.

The first aspect of energy democracy, sustainability, is represented through a regulatory case dealing with bioenergy policy in the EU. As the energy democracy debate fundamentally revolves around the need to shift to and deploy sustainable energy and bioenergy is the most significant form of renewable energy in the $\mathrm{EU}^{6}$ this case study fits well into the chapter. ${ }^{7}$ It is worth noting that although the concepts of renewable energy and sustainable energy are intertwined and sometimes used interchangeably, they have different meanings. Renewable energy generally refers to all renewable non-fossil sources of energy that are replenished by natural processes at a rate that equals or exceeds their rate of use. ${ }^{8}$ The concept of sustainable energy encompasses a broader notion of sustainability to acknowledge the role that energy plays in economic and social development as well as its environmental impact. ${ }^{9}$

Discussing the EU's regulatory approach to forest bioenergy (i.e. forest biomass for bioenergy) as a renewable, sustainable and climate-friendly form of energy, the chapter illustrates the nature of the legal challenges faced by efforts to translate the science around sustainability into concrete legal instruments to enable the energy transition. The EU's current policy approach to forest bioenergy allows its Member States to argue that felling trees just to burn them for

experts. Robin Feldman, The Role of Science in Law (oup 2009) 4-5 and 20o. See also Elizabeth Fisher and others, 'Maturity and Methodology: Starting a Debate about Environmental Law Scholarship' (2009) 21(2) Journal of Environmental Law 213-250, 232-233.

5 See Chapter 1.

6 See e.g. The European Commission's science and knowledge service, 'Facts and figures on bioenergy in the EU', available at <https://ec.europa.eu/jrc/en/science-update/facts-andfigures-bioenergy-eu> accessed 17 June 2020.

7 Jennie C Stephens, 'Energy Democracy: Redistributing Power to the People Through Renewable Transformation' (2019) 61(2) Environment: Science and Policy for Sustainable Development 4-13, 4.

8 Directive (EU) 2018/2001 of the European Parliament and of the Council of 11 December 2018 on the promotion of the use of energy from renewable sources [2018] oJ L328/82 (Renewable Energy Directive, REDII), art 2; Aviel Verbruggen and others, 'Annex I' in Ottmar Edenhofer and others (eds), Special Report on Renewable Energy Sources and Climate Change Mitigation (Intergovernmental Panel on Climate Change 2011) 166.

9 United Nations Economic Commission for Europe (UNECE), Pathways to Sustainable EnergyAccelerating Energy Transition in the UNECE Region, ECE Energy Series No 67 (2020) 3-4. 
energy fully qualifies as low-carbon, renewable energy that is also good for the climate. Advice from almost 800 experts $^{10}$ to the effect that this policy is likely not only to accelerate climate change but jeopardize the integrity of the EU's climate goals was not adequately reflected in the regulatory process. The chapter argues that ignoring the strong scientific arguments against unsustainable regulatory choices severely compromises the core rationale of sustainability that drives the clean energy transition.

Empowered by the specific challenges that arise from an incomplete acknowledgement of science's input into regulatory approaches, the chapter discusses the second aspect. The chapter proposes that science is an important procedural element, in terms of safeguarding procedural justice, in energy justice as the second pillar of sustainable energy democracy. ${ }^{11}$ Procedural justice rests on access to high-quality information, i.e. scientific knowledge about energy, the energy sector and technology, ${ }^{12}$ and requires full and transparent disclosure of information by stakeholders. ${ }^{13}$ Scientific practice is driven by expertise, of which high-quality information and scientific knowledge are products. ${ }^{14}$

This chapter discusses the scientific dimensions of procedural justice in the context of legitimacy. ${ }^{15}$ While 'procedural justice' and 'legitimacy' have

10 'Letter from Scientists to the EU Parliament Regarding Forest Biomass', 9 January 2018, available at <https://www.euractiv.com/wp-content/uploads/sites/2/2018/o1/Letterof-Scientists-on-Use-of-Forest-Biomass-for-Bioenergy-January-12-2018.pdf $>$ accessed 9 June 2020.

11 On procedural justice, see Benjamin K Sovacool and Michael H Dworkin, Global Energy Justice: Problems, Principles, and Practices (Cambridge University Press 2014) 437; Gordon Walker, Environmental Justice: Concepts, Evidence and Politics (Routledge 2012) 47-5o; and Joohee Lee and John Byrne, 'Expanding the Conceptual and Analytical Basis of Energy Justice: Beyond the Three-Tenet Framework', (2019) 7(99) Frontiers in Energy Research $1-10,2$.

12 Sovacool and Dworkin (Global Energy Justice) (n 11) 367 and 373 .

13 Kirsten Jenkins and others, 'Energy justice: A conceptual review' (2016) 11 Energy Research \& Social Science $174-182,178$.

14 Experts are found in the professions and in science, possess technical, manual and intellectual skills, are impartial, which 'makes their advice trustworthy', and are readily distinguishable from non-experts. Furthermore, on information, science 'simply wants to share information about facts'. See Reiner Grundmann, 'The Problem of Expertise in Knowledge Societies' (2017) 55(1) Minerva 25-48, 26 and 41; Harry Collins and Robert Evans, Rethinking Expertise (University of Chicago Press 2007) 3; Lee and Byrne (n 11) 2; and Stephen Turner, 'What is the Problem with Experts?' (2001) 31(1) Social Studies of Science 123-149, 141.

15 Legitimacy is, in principle, about how we accept and justify authority and can be described through its sociological (socially accepted use of authority) and normative (justification; is the use of authority well founded) dimensions. See Daniel Bodansky, 
various uses, definitions and connotations, ${ }^{16}$ they essentially relate, in the context of this chapter, to the inclusion of relevant stakeholders and elements in processes enabling the sustainable energy transition. The concept of procedural justice is narrower than that of legitimacy and concerns how decisions are made and who is involved in making them..$^{17}$ The concept 'manifests as a call for equitable procedures that engage all stakeholders.' ${ }^{18}$ Legitimacy, by contrast, is more of 'a generalized perception or assumption that the actions of an entity are desirable, proper, or appropriate within some socially constructed system of norms, values, beliefs, and definitions.19 The two concepts are intertwined in scholarship relevant to the energy democracy debate ${ }^{20}$ and the connection between the concepts relates especially to processes and outcomes central to democratic energy governance. ${ }^{21}$ The distinction between input and output legitimacy ${ }^{22}$ utilized in this chapter is useful in relation to this context. The decision to analyse the procedural aspects of energy democracy through the lens of legitimacy was also partly methodologically based; the role of science and expertise in processes leading to legitimate and just outcomes is more widely researched in literature on legitimacy. ${ }^{23}$

After analysing both the sustainability and procedural justice aspects in energy democracy, the chapter argues that if science as central procedural requirement is ignored in the regulatory processes central to energy democracy,

'Legitimacy' in Daniel Bodansky, Jutta Brunnée and Ellen Hey (eds), The Oxford Handbook of International Environmental Law (oup 2007) 704-723, 709.

16 Sylvia I Karlsson-Vinkhuyzen, 'Legitimacy' in Christopher K Ansell and Jacob Torfing, Handbook on Theories of Governance (Edward Elgar 2016) 197-204, 197; Kjell Y Törnblom and Riël Vermunt, 'Introduction: Distributive and Procedural Justice', in Kjell Y Törnblom and Riël Vermunt (eds), Distributive and Procedural Justice: Research and Social Applications (Ashgate 2007) 1-12, 1-5.

17 Sovacool and Dworkin (Global Energy Justice) (n 11).

18 Jenkins and others (n 13) 178.

19 Mark C Suchman, 'Managing Legitimacy: Strategic and Institutional Approaches' (1995) 20(3) The Academy of Management Review 571-610, 574.

20 See e.g. Benjamin K Sovacool, Energy and Ethics: Justice and the Global Energy Challenge (Palgrave Macmillan 2013) 70; Szulecki (n 3) 25.

21 Bregje Van Veelen, 'Negotiating energy democracy in practice: governance processes in community energy projects', 27(4) Environmental Politics (2018) 644-665, 645; Burke and Stephens (n 3) 37; Sovacool (n 20) 70; Sovacool and Dworkin (Global Energy Justice) (n 11) 437 .

22 'Input' refers to procedural, and 'output' to substantive elements of legitimacy. Fritz Scharpf, Governing in Europe: Effective and Democratic? (oup 1999) 6 and 24.

23 See e.g. Sylvia I Karlsson-Vinkhuyzen and Jeffrey McGee, 'Legitimacy in an Era of Fragmentation:The Case of Global Climate Governance' (2013)13(3) Global Environmental Politics $56-78,59$. 
the sustainability of clean energy transition as the desired outcome is weakened. A regulatory framework that does not transparently reflect and justify the regulatory choices made by relevant science will be unable to convince society of its ability to facilitate sustainability. As the regulatory case concerning bioenergy in the EU discussed below shows, the relationship between science and lawmaking is rarely straightforward - the outcome of a regulatory deliberation can be unexpected ${ }^{24}$ and inappropriate to the purpose at hand. Science's capacity to contribute to the input of evidence-based scientific knowledge into the regulatory processes makes it an invaluable component in legitimizing the choices made in the sustainable energy transition.

Section 2 of the chapter lays down the framework for the analysis by joining the dots between science, law and energy democracy. Section 3 discusses an example from the EU that illustrates how the sustainable energy transition is facilitated through regulatory instruments and then explains the nature of challenges that can arise from this process. Section 4 provides an analysis of the chapter's key arguments on the role of science in the sustainable energy transition from the two perspectives - sustainability and legitimacy. Section 5 summarizes the key arguments made in the chapter.

What Does Energy Democracy Need Science for?

Scientific knowledge has served both as a driver and informant in relation to the sustainable energy transition for decades, ${ }^{25}$ but its relevance in the more modern context of energy democracy has not yet been extensively assessed. The role of science is acknowledged as a precondition for the proper functioning of law and regulatory frameworks in the context of environmental law, ${ }^{26}$

24 Tim Lougheed, 'Outside Looking In: Understanding the Role of Science in Regulation' (2009) 117(3) Environmental Health Perspectives 105-110, 105.

25 The Oeko-Institut's groundbreaking 'Energy Turnaround' study from 1980 os was a response to the calls for expert knowledge in moving away from oil and nuclear power energy to renewable energy. See Florentin Krause, Hartmut Bossel and Karl-Friedrich MüllerReißmann, Energie-Wende: Wachstum und Wohlstand ohne Erdöl und Uran (Oeko-Institut, Germany 1980); and Craig Morris and Arne Jungjohann, Energy Democracy: Germany's Energiewende to Renewables (Palgrave Macmillan 2016) 29.

26 See e.g. Mary Jane Angelo, 'Harnessing the Power of Science in Environmental Law: Why We Should, Why We Don't, and How We Can' (2008) 86 Texas Law Review 1527-1573; Lawrence Solan and Margaret Berger, 'The Uneasy Relationship Between Science and Law: An Essay and Introduction' (2005) 73 Brooklyn Law Review 847-855; Carol M Rose, 'Environmental Law Grows Up (More or Less), and What Science Can Do To Help?' (2005) 9 (2) Lewis \& Clark Law Review $275^{-282}$. 
climate law ${ }^{27}$ and to some extent also in energy law ${ }^{28}$ discourses. For example, Angelo explains that " $[\mathrm{e}]$ nvironmental law was born out of the new scientific understandings of ecology in the mid-twentieth century'29, and hence 'no good environmental (or energy) law and policies can emerge if not taking full account of and implementing (sound) scientific advice.'30

Scientific knowledge provides sustainable energy democracy with a sound understanding of the underlying challenges related to decarbonization and restructuring of the energy sector toward renewable energy. ${ }^{31}$ These challenges range from the need for innovations and technological development ${ }^{32}$ to social acceptability ${ }^{33}$ and feasibility of different renewable energy solutions. ${ }^{34}$ These challenges are all part of the systemic imperative to take immediate action across economic sectors to mitigate climate change and to shift to cleaner forms of energy, while also ascertaining sustainability. The nature of this task requires vast changes and actions in society and across all economic sectors that are correctly timed, effective, accepted and result in the desired outcomes. Stern, Sovacool and Dietz argue that the linked problems of energy sustainability and climate change, as the most complex challenges of our time, require 'an integrated scientific approach that engages the social sciences along with the natural sciences and engineering. ${ }^{35}$ This entails that the regulatory and legislative decisions we take in the sustainable energy transition should be verified

27 See e.g. Frank Fischer, Citizens, Experts, and the Environment: The Politics of Local Knowledge (Duke University Press 200o).

28 See e.g. Donald Zillman and others, 'Introduction. How Technological and Legal Innovation Are Transforming Energy Law', in Donald Zillman and others (eds), Innovation in Energy Law and Technology: Dynamic Solutions for Energy Transitions (OUP 2018) 1-19; Karen Makuch and Ricardo Pereira, Environmental and Energy Law (Wiley-Blackwell 2012) 5-6.

29 Angelo (n 26) 1527.

$30 \quad$ Makuch and Pereira (n 28) 5 .

31 Szulecki (n 3) 22; Burke and Stephens (n 3) 44-45; Kathleen Araújo, 'The emerging field of energy transitions: Progress, challenges, and opportunities' (2014) Energy Research \& Social Science 112-121, 117-118; Benjamin K Sovacool and Michael H Dworkin, 'Energy justice: Conceptual insights and practical applications' (2015) 142 Applied Energy 435-444, 439; Burke and Stephens (n 3) 35 .

32 Burke and Stephens (n 3) 44-45.

33 Raphael J Heffron and Darren McCauley, 'What is the "Just Transition"?' (2018) 88 Geoforum 74-77, 76 .

34 Such as e.g. Renewable Energy Prospects for the European Union (European Union and IRENA 2018), available at <https://www.irena.org/-/media/Files/IRENA/Agency/ Publication/2018/Feb/IRENA_REmap_EU_2018.pdf> accessed 22 June 2020.

35 Paul Stern, Benjamin K Sovacool and Thomas Dietz, 'Towards a science of climate and energy choices' (2016) 6 Nature Climate Change 547-555, 547-548. 
by the scientific community and adapted in accordance with new scientific knowledge.

Experts possess the 'power to define problems' and, through this capacity, speak to policymakers and moreover, to the society as the perhaps most important audience. ${ }^{36}$ Droste-Franke and others explain that an important task for science is to reveal to decision-makers the interlinkages between actions, framework conditions (i.e. the prevailing circumstances), and their impact. ${ }^{37}$ In decisions relevant to energy, good expert advice is acceptable within 'a wide spectrum of diverse interests and value commitments'. ${ }^{38}$ Scientific knowledge can hence be seen to ensure 'continuous acceptance and validity of the recommendations made' and favours its political realization. ${ }^{39}$ In the context of energy democracy and renewable energy, Rountree and Baldwin find that not only are experts central stakeholders participating in formal regulatory processes, but that meaningful participation (i.e. the ability to influence decisions) may even be limited to experts. Although a wide range of stakeholders, such as utilities, electricity generators, and private citizens, participate in decision-making concerning renewable energy, not all stakeholder groups are able to influence formal processes and decision-making. ${ }^{40}$

Szulecki opines that energy democracy must always rely on the 'responsiveness of experts and policymakers, even if some areas of governance need to be continuously dominated by expert knowledge'.41 This is the case because the energy sector is characterized by technological complexity and depends on the availability of technical expertise to deal with its problems. The energy sector has traditionally been presented as a 'technoscientific domain reserved for experts. ${ }^{42}$ Decisions of a technical nature can be viewed as 'best left' to experts, because non-experts do not necessarily adequately understand the issue at hand and the technologies and potential risks involved. ${ }^{43}$ Due to the

36 Szulecki (n 3 ) 29-30. See also Fischer and Ivanova (n 27), 31; Van Veelen and van der Horst (n 3 ) 23 .

37 Bert Droste-Franke and others, Improving Energy Decisions: Towards Better Scientific Policy Advice for a Safe and Secure Future Energy System (Springer 2015) xxiii.

38 ibid.

39 ibid.

40 Valerie Rountree and Elizabeth Baldwin, 'State-Level Renewable Energy Policy Implementation: How and Why Do Stakeholders Participate?' in Andrea M FeldpauschParker and others (eds), Energy Democracy: A Research Agenda (Frontiers Media 2019) 7184,81 .

41 Szulecki ( $\left.\mathrm{n}_{3}\right)_{31}$.

42 ibid 29.

43 Rountree and Baldwin (n 40) 74. 
very technical nature of the energy sector, some literature even draws a distinction between scientific experts, who base their recommendation on science; and technical experts, who know how to follow the rules in an energy-specific context. ${ }^{44}$

Overall, scientists and scientific institutions have become active and central participants in sustainability governance. Although science provides law with invaluable knowledge input, the relationship between science and lawmaking is not always rosy. ${ }^{45}$ Problems emerge, for example, due to lack of insight into the other's realm, in the context of how to apply scientific knowledge in regulatory processes or in relation to blurred demarcation over who claims authority in the regulatory process.

The approaches taken to applying scientific knowledge often vary. A 'pure scientist has no interest in the decision-making process and simply wants to share information about facts'. ${ }^{6}$ Scientists might assume that when policymakers and legislators are confronted with questions of scientific evidence, they will apply a 'weight of the evidence' approach and view available knowledge as a composite of strengths and weaknesses. ${ }^{47}$ However, instead of incorporating science into policy by using purely best knowledge, the legal system makes decisions through an adversarial process. This adversarial process is driven by affected parties' interests, and the parties interpret the available knowledge in a way that matches their interests. ${ }^{48}$

Regulatory decision-making is governed by laws, regulations and policies and carried out by policymakers, legislators and lawyers. ${ }^{49}$ As the authoritative provider of knowledge, science can push for an authoritative role in governance. ${ }^{50}$ Feldman describes how law can turn to science even to bestow on science the power to resolve 'uncomfortable' legal dilemmas, and expect science to provide answers. ${ }^{51}$ In accordance with the principle of separation of

44 Droste-Franke and others (n 37) xxv.

45 Feldman (n 4) 200; Solan and Berger (n 26) 848-85o.

46 Grundmann (n 14) 41.

47 Wendy Wagner and Rena Steinzor, 'Introduction: Principled Science' in Wendy Wagner and Rena Steinzor (eds), Rescuing Science from Politics: Regulation and the Distortion of Scientific Research (Cambridge University Press 2010) 1-20, 3-4.

48 ibid.

49 Jonathan W Moore and others, 'Towards linking environmental law and science’ (2018) 3 Facets 375-391, 375.

$50 \quad$ Feldman (n 4) 37; Sandra van der Hel and Frank Biermann, 'The authority of science in sustainability governance: A structured comparison of six science institutions engaged with the Sustainable Development Goals' (2017) 77 Environmental Science and Policy 211220, 212 and 217-218. 
powers, this authoritative role is usually claimed by the legislature. ${ }^{52}$ If legislators relied on science to craft rules, the rules would lack the 'flexibility and dexterity 53 that emerge in the processes of legal evolution through legal analysis. ${ }^{54}$ Hence the main entry point for science to influence law is through lawmaking processes pursued by the legislator. In the context of the EU, it is the responsibility of the European Commission, which has the right of legislative initiative within the EU legislative context, to assess the complex 'scientific realities and the difficult choices to be made in this respect'. 55

Finally, the challenges that attach to the sustainable energy transition are not only problems of science or law alone, but to a very large extent also problems of politics. Those engaged in the development of policy or law can 'ask questions as if they were scientific questions, when actually they are political questions, and sometimes we mix things up and try to respond to political questions using strictly scientific criteria'.56 The regulatory decisions required by the sustainable energy transition are often (tricky) political questions - the energy transition is primarily a political struggle. ${ }^{57}$ The regulatory processes for the sustainable energy transition not only balance the authority of science against that of lawmaking, but must also weigh up the processes needed to adapt to prevailing political circumstances in a given regulatory jurisdiction. Ruhl argues, in the context of environmental law, that the politicization of science and the scientization of policy decision-making have become endemic and mutually reinforcing. ${ }^{58} \mathrm{It}$ is a phenomenon already inherent in the formal regulatory processes.

To summarize, the relationship between science and lawmaking is anything but straightforward. The outcome of a regulatory process can sometimes be unexpected, and even inconsistent with the regulatory objectives. Science does not have a normative role in lawmaking, and it is the exclusive right of the legislator to exercise legislative discretion to draft and pass laws. However, science is gaining a more prominent role in lawmaking, both as an invited

52 See e.g. Bas van der Vossen, 'Assessing Law's Claim to Authority' (2011) 31(3) Oxford Journal of Legal Studies 481-501, 481; Horacio Spector, 'A Pragmatic Reconstruction of Law's Claim to Authority' (2019) 32(1) Ratio Juris 21-48, 21.

53 Feldman (n 4$) 200$.

54 See e.g. van der Hel and Biermann (n $5^{\circ}$ ) 211; Feldman (n 4) 38-39.

55 Allan Rosas, 'Separation of Powers in the European Union' (2007) 41(4) The International Lawyer 1033-1046, 1040.

56 Lougheed (n 24) 109 .

57 Matthew J Burke and Jennie C Stephens, 'Political power and renewable energy futures: A critical review' (2018) 35 Energy Research \& Social Science 78-93, 78. 
participant that informs the legislator on the underlying preconditions and as one that has the ability to assess the outcome expected from a given regulatory framework..$^{59}$ There is a need for inclusive dialogue between the dependency on science's facts and laws crafting skills to produce rules for the sustainable energy transition and to foster energy democracy. Lawmaking and science evolve together in a process that is 'continually in flux' and often under (e.g. political) stress. ${ }^{60}$ Energy democracy is based on a 'democratic storyline' that primarily builds on the inclusion of a wider group of actors and stakeholders that are all interested in contributing to commonly agreed goals, such as decarbonization and the sustainable energy transition. ${ }^{61}$ Science is a crucial stakeholder in this storyline.

Trouble in Transition: A Mismatch between Science and Lawmaking in the EU's Approach to Bioenergy

\section{1}

The Science's View on Sustainable Bioenergy

The case of forest bioenergy offers a practical example of the way in which a disconnect between science and lawmaking may undermine the effectiveness of lawmaking and jeopardize the sustainability of expected outcome in the energy democracy framework. The EU envisages a future power sector largely based on renewable sources, complemented by the rapid phasing-out of traditional fossil-based sources of energy. ${ }^{62}$ Bioenergy produced from biomass resources ${ }^{63}$ is the largest source of renewable energy in the EU (with a share of almost $6 \circ \%$ ) and will continue to be so beyond 2030. ${ }^{64}$ Bioenergy refers generally to energy derived from any form of biomass, including forest

59 Rob van Gestel and Jurgen de Poorter, 'Putting evidence-based law making to the test:judicial review of legislative rationality' (2016) 4(2) The Theory and Practice of Legislation $155^{-185}, 156$.

6o ibid 1066.

61 Carolyn M Hendriks, 'Policy design without democracy? Making democratic sense of transition management' (2009) 42 Policy Sciences 341-368, 354-356 and 36o.

62 Communication from the Commission, 'The European Green Deal', сом(2019) 640 final, 2.

63 'Biomass' refers to 'the biodegradable fraction of products, waste and residues from biological origin from agriculture, including vegetal and animal substances, from forestry and related industries, including fisheries and aquaculture, as well as the biodegradable fraction of waste, including industrial and municipal waste of biological origin'. REDII, art 2.

64 Göran Berndes and others, 'Forest biomass, carbon neutrality and climate change mitigation', 3 From Science to Policy (European Forest Institute 2016) 5 . 
biomass for bioenergy. The concept of bioenergy is not defined in EU law. ${ }^{65}$ The role of forests as providers of bioenergy resources is steadily growing as countries seek ways to phase out fossil-fuel based energy. ${ }^{66}$ At the same time forests are of central relevance to climate change mitigation by acting both as sinks ${ }^{67}$ and sources ${ }^{68}$ of greenhouse gas (GHG) emissions. Forests and the biomass resources held within them have the capacity to both take in and release carbon. Forests sequester carbon by capturing $\mathrm{CO}_{2}$ from the atmosphere and storing it in biomass through photosynthesis. Forests emit carbon back into the atmosphere due to natural causes, such as forest fires, or due to human activities, such as deforestation and biomass combustion for bioenergy. Hence depending on the special characteristics and usage of the specific substance in question, forest biomass can play various roles in the carbon cycle, from net sinks of carbon to net emitters of carbon.

With most nations making too slow progress in carbon emissions control, ${ }^{69}$ greater attention is being paid to carbon emissions and removals from land, land use and forests. ${ }^{70}$ Despite all the potential vested in forest bioenergy, ${ }^{71}$ the use of forest bioenergy comes with considerable scientific uncertainties that relate to sustainability. The most alarming sustainability concern relates to its climate performance, i.e. the potential of forest-based bioenergy to produce

65 Berndes and others (n 64) 4-6.

66 ibid.

67 Under art 3 of Regulation (EU) 2018/841 of the European Parliament and of the Council of 30 May 2018 on the inclusion of greenhouse gas emissions and removals from land use, land use change and forestry in the 2030 climate and energy framework and amending Regulation (EU) No 525/2013 and Decision No 529/2013/EU [2018] OJ L156/1 (the 'LULUCF Regulation'), a 'sink' is 'any process, activity or mechanism which removes a greenhouse gas, an aerosol or a precursor of a greenhouse gas from the atmosphere'.

68 Under art 3 of the LULUCF Regulation, a 'source' is 'any process, activity or mechanism that releases a greenhouse gas, an aerosol or a precursor to a greenhouse gas into the atmosphere'. 'Removals' refer to the withdrawal of GHGs from the atmosphere either through biological sinks of $\mathrm{CO}_{2}$ or through deliberate human activities (such as carbon capture and storage technologies).

69 Climate Action Tracker, 'Global update: Governments still showing little sign of acting on climate crisis', available at <https://climateactiontracker.org/publications/governmentsstill-not-acting-on-climate-crisis/> accessed 8 June 2020.

70 See e.g. Gert-Jan Nabuurs and others, 'A New Role for Forests and the Forest Sector in the EU Post-2020 Climate Targets' (European Forest Institute 2015) 3.

71 Forest bioenergy refers to renewable energy produced from forest residue or co-products of industrial wood-processing operations. Andrea Camia and others, 'Biomass production, supply, uses and flows in the European Union: First results from an integrated assessment', Joint Research Centre (JRC) Science for Policy Report (Publications Office of the European Union 2018) 29-46. 
GHG savings or bioenergy being a neutral form of energy that does not exacerbate climate change. ${ }^{72}$ Concerns over the climate impacts of the use of forest bioenergy centre around the concept of carbon neutrality that refers to the presumption that the carbon emitted from living organisms into the atmosphere is offset by forest regrowth. ${ }^{73}$

The assumption of carbon neutrality is problematic, and science explains why. ${ }^{74}$ How much time is needed for the emissions resulting from the use of forest biomass for bioenergy to be compensated for by regrowth of the forests? ${ }^{75}$ This is called the 'payback time.' ${ }^{76}$ Scientific studies confirm that when bioenergy is produced from forest residues, the payback time 'may be of the order of years. ${ }^{77}$ However, if more trees are harvested the payback time may range from decades to centuries. Given the urgency of climate measures, this is too long to wait for the reabsorption of carbon from the burning of biomass. Moreover, the ability of renewable energy to replenish does not necessarily equate to sustainability. Time matters - if it takes from decades to centuries for forest carbon stock to replenish, should we consider the energy source as renewable? And furthermore, would such renewable energy constitute sustainable energy?

The use of forest residue and wastes for bioenergy production can have climate change mitigation potential. However, the range of forest bioenergy sources used as renewable forms of energy is no longer limited to forest residues but has already been expanded to include whole trees. ${ }^{78}$ The global decarbonization agenda signals urgency, and calls for a rapid reduction in

72 Almut Arneth and others, 'Summary for Policymakers' in Valerie Masson-Delmotte and others (eds), Climate Change and Land: an IPCC special report on climate change, desertification, land degradation, sustainable land management, food security, and greenhouse gas fluxes in terrestrial ecosystems (Intergovernmental Panel on Climate Change 2020) 21.

73 IEA Bioenergy, 'Carbon neutrality', available at <https://www.ieabioenergy.com/ieapublications/faq/woodybiomass/carbon-neutrality/> accessed 8 June 2020.

74 Michael Norton and others, 'Serious mismatches continue between science and policy in forest bioenergy' (2019) 11 Global Change Biology Bioenergy, 1256-1263, 1257-1258; Mary Booth, 'Not carbon neutral: Assessing the net emissions impact of residues burned for bioenergy' (2018) 13 Environmental Research Letters 1-11, 1.

75 See e.g. Giuliana Zanchi, Naomi Pena and Neil Bird, 'Is woody bioenergy carbon neutral? A comparative assessment of emissions from consumption of woody bioenergy and fossil fuel' (2012) 4 Global Change Biology Bioenergy 761-772, 761 .

$76 \quad$ Norton and others (n 74) 259.

77 ibid.

$7^{8}$ Jaana Bäck and others, 'Multi-functionality and sustainability in the European Union's forests', European Academies Science Advisory Council (EASAC) policy report 32 (EASAC 2017), available at <https://www.easac.eu/fileadmin/PDF_s/reports_statements/Forests/ EASAC_Forests_web_complete.pdf $>$ accessed 8 June 2020, 21-22. 
global temperatures over the next few decades. In other words, forest bioenergy should not be regarded as climate-friendly renewable energy 'unless the replacement of fossil fuels by biomass leads to net reductions in atmospheric concentrations of $\mathrm{CO}_{2}$ within a decade or so.' ${ }^{79}$

In addition, burning biomass for energy produces carbon emissions, as does burning coal, oil or gas. The combustion of biomass generates gross G HG emissions 'roughly equivalent' to the combustion of fossil fuels. ${ }^{80}$ G HG emissions produced by burning biomass are no greener than those produced by burning fossil fuels. ${ }^{81}$ Finally, only the use of 'additional biomass', i.e. biomass from additional plant growth or biomass that would decompose quickly if not used for bioenergy has the potential to reduce carbon emissions. ${ }^{82}$ Hence the use of bioenergy as an alternative to fossil fuels does not, per se, decrease G HG emissions. ${ }^{83}$ Scientific insight is crucial in order to understand the nature and scale of the challenges associated with assuming that bioenergy is carbon neutral. The next section explains how this scientific insight has been translated into legal instruments.

\subsection{Sustainable Forest Bioenergy in Law}

EU law currently treats forest bioenergy as a renewable, sustainable form of energy that is good for the climate. Forest bioenergy is placed in the same renewable energy category as, for example, wind and solar energy. The two relevant legal instruments are the REDII and the LULUCF Regulation. Both are key components of the EU climate and energy framework for 2030.

REDII also applies to forest biomass ${ }^{84}$ for bioenergy and treats it as a form of renewable energy that can be measured against the EU's renewable energy targets if the conditions for doing so are met. The conditions in question are safeguards under EU law as to the sustainability of the resource (i.e. sustainability criteria, including the new LULUCF criteria) ${ }^{85}$ and the requirement that this form of energy performs better in terms of GHG emissions than its fossil fuel counterpart (i.e. G HG emission savings and the calculation of such savings). ${ }^{86}$

\footnotetext{
79 Norton and others (n 74) 1259.

80 See e.g. Felix Creutzig and others, 'Bioenergy and climate change mitigation: an assessment' (2015) 7 Global Change Biology Bioenergy 916-944, 924.

81 Booth (n 74) 1-2.

82 Helmut Haberl and others, 'Correcting a fundamental error in greenhouse gas accounting related to bioenergy' (2012) 5 Energy Policy 18-23, 18.

83 Norton and others (n 74) 1259.

84 REDII, art 1 and art 2(24) and (26).

85 REDII, art 29.

86 REDII, art 31.
} 
The 'sustainability' of renewable energy, including the climate performance of forest bioenergy, has been set as a precondition for renewable energy use in the EU. ${ }^{87}$ This aspect also highlights the underlying dichotomy between the concepts of renewable energy and sustainable energy.

The purpose of the EU-wide sustainability and GHG savings criteria for biomass fuels used in the electricity sector and in the heating and cooling sector is to 'ensure high' G HG emission savings compared to fossil fuel alternatives. ${ }^{88}$ In other words, the use of biomass fuels must result in G HG emission savings. Under this legislative framework, carbon emissions calculated from forestbased bioenergy are zero-rated. ${ }^{89}$ This means that emissions resulting from the use of forest bioenergy, for example, for biofuels or the combustion of forest bioenergy, are not included in the accounting. In other words, burning of biomass does not cause emissions in this accounting, due to zero-rating.

The responsibility for measuring bioenergy's carbon footprint is shifted away from the scope of the REDII to that of the LULUCF Regulation. The emissions of biomass used in energy are recorded and counted towards the EU's 2030 climate commitments through the LULUCF sector's accounting rules. ${ }^{90}$ The LULUCF Regulation comprises the new component to the EU 203 o climate and energy policy framework. The Regulation's key commitment is that emissions may not exceed removals within the LULUCF sector (the no debit rule). ${ }^{91}$ In addition to this legal requirement, the Regulation lays down a detailed accounting framework ${ }^{92}$ for calculating emissions and removals from different land use categories to comply with the no debit rule. It should be noted, however, that the LULUCF Regulation accounts for emissions of bioenergy as changes in forests' carbon resources (i.e. harvesting reduces the amount of forest biomass), not emissions when the biomass is burned.

The Regulation's most important instrument is the forest reference level (FRL), which constitutes an accounting approach used to account for emissions

\footnotetext{
87 See e.g. REDII, recital 94.

88 REDII, art 29(10) and recital 101.

89 REDII, Annex V, C., para. 13 and Annex VI, B. para 13; Directive 2003/87/EC of the European Parliament and of the Council of 13 October 2003 establishing a scheme for greenhouse gas emission allowance trading within the Community and amending Council Directive 96/61/EC [2003] OJ L275/32 (the 'EU Emissions Trading Directive' or 'EU ETS Directive') 32, Annex IV, Part A. and B; Commission Regulation (EU) No 6o1/2012 of 21 June 2012 on the monitoring and reporting of greenhouse gas emissions pursuant to Directive 2003/87/ EC of the European Parliament and of the Council [2012] OJ L181/3o, art 38.

9o LULUCF Regulation, recital 15.

91 ibid art 4.

92 ibid arts 5 to 10.
} 
and removals of carbon on managed forest land. The managed forest land accounting category includes the emissions from the use of forest biomass for energy. In very simple terms, the FRL entails comparison of the change in the forest carbon sink as against the level at an earlier point in time and aims to capture only the impacts of changes in forest management practices. ${ }^{93}$ Depending on the reference level, increasing the use of the forest biomass will decrease the sink (i.e. cause carbon emissions) and the resulting debit needs to be compensated for by emissions reductions in other sectors. If the FRL is met and exceeded (i.e. removal of carbon), the excess can be used for compliance, for example in other land accounting categories. ${ }^{94}$

The rules on the $\mathrm{FRL}^{95}$ are highly technical and complex and allow for different conceptions of their application. ${ }^{96}$ In reality, the rules have proven difficult for national policymakers to apply. ${ }^{97}$ Overall, the LULUCF Regulation establishes the process of calculating the FRLs as a two-way process involving both the Commission and the national authorities of a Member State. ${ }^{98}$ In line with the fact that forest policy does not fall under the EU's competences, the Regulation provides the Member States with wide discretion in establishing their national FRLs. However, this is accompanied by a great degree of uncertainty in relation to the various ways in which FRLs can be set. ${ }^{99}$

93 Alan Matthews, 'Accounting for the LULUCF sector in the EU's 2030 climate targets', available at <http://capreform.eu/accounting-for-the-lulucf-sector-in-the-eus-203o-climatetargets $/>$ accessed 9 June 2020 .

LULUCF Regulation, arts 11 to 13 .

95 ibid art 8(5).

96 For a thorough analysis of the LULUCF Regulation and its normative elements, see Seita Romppanen, 'The LULUCF Regulation: The New Role of Land and Forests in the EU Climate and Policy Framework', (2020) Journal of Energy \& Natural Resources Law 261-287.

97 Several Member States have been requested to revise their FRLs. Commission Staff Working Document, Assessment of the National Forestry Accounting Plans. Regulation (EU) 2018/841 of the European Parliament and of the Council on the Inclusion of Greenhouse Gas Emissions and Removals from Land Use, Land Use Change and Forestry in the 203o Climate and Energy Framework, and Amending Regulation (EU) No 525/2013 and Decision No 529/2013/EU, SWD (2019) 213 final.

98 Lulucf Regulation, arts 8(6) and 8(8). Annalisa Savaresi, Lucia Perugini and Maria Vincenza Chiriacò, 'Making sense of the LULUCF Regulation: Much ado about nothing?' (2020) 29 Review of European, Comparative and International Environmental Law (RECIEL) 212-220; Hannes Böttcher and others, EU LULUCF Regulation explained: Summary of core provisions and expected effects, (Oeko-Institut 2019). Romppanen (LULUCF) (n 96) 26. 
To summarize, the REDII treats forest biomass for bioenergy as a renewable energy, considers it as carbon neutral ${ }^{100}$ when calculating its G HG impact, and shifts the responsibility for accounting for its carbon performance to the LULUCF Regulation. This primarily entails that the current approach places enormous trust in the way in which these emissions are reflected in the LULUCF sector's accounting. The nature of the demarcation between the two regulatory instruments would be acceptable if it entailed abolition of the erroneous treatment of forest biomass as carbon neutral. This is, unfortunately, not possible because the FRL rules under the LULUCF Regulation are insufficiently robust to ensure adequate and transparent consideration of these emissions. The rules are complex and difficult to apply, but leave ample room for national discretion. ${ }^{101}$ The LULUCF Regulation was very much a political challenge, from the outset of the regulatory process, and the complex but flexible rules that resulted reflect the technically challenging but politically sensitive regulatory process that took place. ${ }^{102}$

The FRL $s$ adopted should account for climate consequences in a transparent and reliable manner and establish a credible, science-based benchmark against which to ascertain the positive climate performance of forest bioenergy. ${ }^{103}$ The success of this benchmark would require the Member States to employ the discretion afforded by the framework laid down under the LU LUCF Regulation with rigour and high ambition. In its current form, the LULUCF Regulation is not strong enough in terms of demanding this ambition. The approach taken allows for too many uncertainties and affords the Member States too much room for manoeuvre as to the establishment of the FRLs. Consequently, how ambitiously and honestly the FRLs reflect the climate impacts of forest bioenergy remains unclear. These aspects combined weaken the effectiveness of the LULUCF Regulation given that forest bioenergy is set to play a pivotal role in the EU's renewable energy transition agenda.

The treatment of forest bioenergy in EU law demonstrates how obscurities in the science and lawmaking interface can blur the underlying rationale of making our energy more sustainable. The above analysis explains that although science underlines the problems related to using forest biomass for energy, this

100 The assumption of carbon neutrality originates from the Intergovernmental Panel on Climate Change's (IPCC) Guidelines for G HG inventories. IPCC, 'Refinement to the 2006 IPCC Guidelines for National Greenhouse Gas Inventories: Volume 2: Energy', available at $<$ https://www.ipcc-nggip.iges.or.jp/public/201grf/vol2.html> accessed 9 June 2020.

101 Romppanen (LULUCF) (n 96) 286.

102 See e.g. Savaresi, Perugini and Chiriacò (n 98) 213-214.

103 Romppanen (LULUCF) (n 96) 278; Savaresi, Perugini and Chiriacò (n 98) 215. 
knowledge is not fully reflected in the regulatory framework that applies to bioenergy's climate performance in the EU. The example exemplifies the challenges that relate to the attempt to reconcile mutually conflicting regulatory objectives (increasing the share of renewable energy while fully accounting for the emissions of bioenergy) in the sustainable energy transition. These challenges raise the risk that the regulatory framework for bioenergy will worsen rather than mitigate climate change, and results in more unsustainable energy.

\section{$4 \quad$ Connecting the Science-Law Interface to Legitimizing the Sustainable Energy Transition}

\subsection{An Example: Compromised 'Sustainability' in the Energy Transition}

Concerns relating to sustainability ${ }^{104}$ are at the heart of the transition to cleaner, renewable forms of energy. However, the forest bioenergy case study discussed above shows that the renewability of renewable energy does not automatically ensure that these sources are sustainable for the environment or climate. In other words, sustainable does not equal low carbon, ${ }^{105}$ and switching to renewable energy does not automatically make the energy transition sustainable. ${ }^{106}$

A letter sent to the European Parliament, signed by almost 800 experts, ${ }^{107}$ stated that the EU's policy on forest bioenergy would not only accelerate climate change but also jeopardize the integrity of the EU's climate goals. It delivered a strong message from the scientific community to the EU legislator, asking the latter to amend the REDII to better reflect the impacts of burning forest bioenergy. The signatories suggested that RED II be revised to restrict the forest bioenergy eligible under the directive only to forest residues and wastes. ${ }^{108}$

However, despite the scientific community's clear message that harvesting wood for burning 'will increase carbon in the atmosphere and warming

\footnotetext{
104 Sustainability is centrally determined through three preconditions: environmental sustainability, social sustainability and economic sustainability. Ben Purvis, Yong Mao and Darren Robinson, 'Three pillars of sustainability: in search of conceptual origins' (2019) 14 Sustainability Science 681-695, 681.

105 Timothy D Searchinger and others, 'Europe's renewable energy directive poised to harm global forests' (2018) 9 Nature Communications 1-4, 1.

106 David Elliot (ed), Sustainable Energy: Opportunities and Limitations (Palgrave Macmillan 2007) xii-xiii; and Penelope Crossley, Renewable Energy Law: An International Assessment (Cambridge University Press 2019) 17-62.

107 'Letter from Scientists to the EU Parliament Regarding Forest Biomass'.

108 ibid.
} 
for decades to centuries - even when wood replaces coal, oil or natural gas' the EU persisted with the approach it had embarked upon. ${ }^{109}$ In the travaux préparatoires for the REDII, the zero rating of biomass combustion is briefly touched upon, without clear reference to challenges related to the assumptions as to carbon neutrality. For example, the impact assessment on sustainability of bioenergy states that the 'zero rating has often been misinterpreted as meaning that biomass combustion emissions are always compensated by regrowth ('carbon neutrality'),'110 but contains no further discussion of the grounds for this misinterpretation. Instead, the impact assessment explains that the emissions from biomass combustion are now accounted for under the LULUCF sector (especially under the category of managed forest land) and this justifies the zero rating of biomass in the energy sector. ${ }^{111}$ As explained above, this would indeed offer such justification if the LULUCF Regulator's accounting were capable of full, clear and straightforward inclusion of these emissions. Due to the challenges discussed above relating to the accounting rules per se, this is not, however, the case. Instead of the responsibility of ascertaining the appropriate climate performance of forest bioenergy being laid down under the LULUCF Regulation, stronger precautions could have been taken within the REDII legislative process in relation to the sustainability implications and climate impacts of burning biomass for energy. Alternatively, the LULUCF Regulation should contain a coherent, clear and solid set of accounting rules applicable to emissions of biomass used in energy.

The robustness of the current legislative framework has been questioned both in literature ${ }^{12}$ and in proceedings before the General Court of the EU. ${ }^{113}$ The case of Sabo - sometimes also referred to as the 'EU Biomass Case' involved a challenge concerning the treatment of all forest bioenergy (not only residues and wastes) as a renewable and carbon neutral fuel. This

109 ibid.

110 'Sustainability of Bioenergy', commission staff working document, impact assessment to the proposal for a Directive of the European Parliament and of the Council on the promotion of the use of energy from renewable sources (recast), $\operatorname{swD}(2016) 418$ final, part $4 /$ 4, 17-18.

111 ibid 17,22 and 39.

112 Norton and others (n 74); Berndes and others (n 64); Bäck and others (n 78); Böttcher and others (n 98); Seita Romppanen, 'The Bioenergy 'Blind Spots' in EU Climate and Energy Law' (2020) 29(4) European Environmental \& Energy Law Review 150-162.

113 'EU Biomass Legal Case', available at <http://eubiomasscase.org/> and 'People's Climate Case', available at <https://peoplesclimatecase.caneurope.org/what-we-want/> both accessed 8 June 2020. Application for Annulment pursuant to Article 263 TFEU, Peter Sabo (on behalf of wolf forest protection movement) and others as applicants and The European Parliament and The European Council as defendants. 
application was dismissed by the Court as inadmissible. ${ }^{114}$ The case highlights the serious problems involved in the treatment of forest biomass as a renewable and climate-friendly bioenergy. Moreover, it exemplifies the legal challenges related to efforts to translate sustainability into specific legal instruments to steer the clean energy transition. The case underlined the science/policy interface, as the applicants argued that the EU legislator failed to take account of relevant scientific and technical data regarding the potential for forest bioenergy harvesting and combustion. The applicants were not ready to accept the legislator's opaque acknowledgement of scientific knowledge, because the regulatory choices made do not adequately reflect this knowledge. ${ }^{115}$

\subsection{Input and Output Legitimacy Aspects}

The omissions relating to the proper acknowledgement of science in regulatory frameworks crucial to the energy transition bring forward distinct procedural aspects in the context of energy democracy. This section discusses these issues in the context of legitimacy. For the purposes of this chapter, utilization of the concepts of input and output legitimacy offer a pragmatic means of further analysing concerns related to the science/law mismatch that results in compromised sustainability.

There are different ways to categorize the procedural elements of legitimacy. For example, Bodansky distinguishes between source-based legitimacy, process-based legitimacy, and outcome-based legitimacy, ${ }^{116}$ whereas Scharpf explains the different legitimacy components by reference to the concepts of input and output legitimacy. Input legitimacy is gained from governance processes, and output legitimacy from the outcome. ${ }^{117}$ Input legitimacy is interested in the legitimacy of the decision-making process itself and checks whether the process meets procedural requirements, such as representation of relevant stakeholders, transparency and accountability. Output legitimacy focuses on the legitimacy of the results and deals with the effectiveness or

\footnotetext{
114 Case T-141/19, Sabo and Others $v$ Parliament and Council, ECLI:EU:T:2O2O:179.

115 'EU Biomass Legal Case' ( $\mathrm{n}$ 115).

116 Daniel Bodansky, 'The Legitimacy of International Governance: A Coming Challenge for International Environmental Law?' (1999) 93(3) The American Journal of International Law 596-624, 612.

117 Input legitimacy refers to fair process based on fundamental democratic norms (e.g. good governance, public participation), while output legitimacy refers to an effective and equitable outcome as well as to problem-solving capacity (e.g. expertise, performance delivery). Scharpf (n 22) 6 and 24; Karlsson-Vinkhuyzen (n 16) 198.
} 
'problem solving capacity' of the governance system. ${ }^{118}$ These concepts partly overlap, for example in relation to the source of legitimacy and its effectiveness (i.e. what is the nature of the norms produced in governance and does the governance produce desired results or changes). ${ }^{119}$ The source and process-based legitimacy components coincide in the context of input legitimacy. ${ }^{120}$

The notions of procedural justice and legitimacy are linked via processes and outcomes central to democratic energy governance. ${ }^{121}$ For energy democracy, the distinction between input and output legitimacy can be captured by asking whether the processes of decision-making in the energy transition meet the procedural requirements and whether they deliver the promised outcome. In this context, 'processes' refers to establishment of the regulatory frameworks for the clean energy transition whereas the outcome refers to the objective - the shift to more sustainable renewable energy that contributes to decarbonization. ${ }^{122}$ In these processes, science is a provider of legitimacy (i.e. source-based, input legitimacy). ${ }^{123}$ In other words, it is an important element in energy democracy because of the invaluable evidence-based input only science is able to contribute to the regulatory processes for the sustainable energy transition. Hence science and expertise play a fundamental role in legitimizing energy governance for energy democracy. ${ }^{124}$

The input and output legitimacy framework can be applied to the practical example of forest bioenergy discussed above. In this context, the science on forest bioenergy, and assumptions as to its carbon neutrality contribute towards input legitimacy. The desired result - i.e. the underlying precondition of sustainability of the renewable energy we are switching to - should deliver output legitimacy. As discussed above, the current regulatory framework for forest bioenergy does not fully acknowledge the well-founded concerns relating to climate performance of forest bioenergy, and hence the process does

118 Arild Vatn, Environmental Governance: Institutions, Policies and Actions (Edward Elgar 2016) xx; Karin Bäckstrand, 'Multi-Stakeholder Partnerships for Sustainable Development: Rethinking Legitimacy, Accountability and Effectiveness' (2006) 16(5) Environmental Policy and Governance 290-306, 291-292.

$119 \operatorname{Vatn}(\mathrm{n} 118) \mathrm{xx}$.

120 Karlsson-Vinkhuyzen and McGee (n 23) $5^{8-59}$.

121 Bregje Van Veelen, 'Negotiating energy democracy in practice: governance processes in community energy projects' (2018) 27(4) Environmental Politics 644-665, 645; Burke and Stephens (n 3) 37; Sovacool (n 20) 70; Sovacool and Dworkin (Global Energy Justice) (n 11) 437 .

122 Bäckstrand (n 118) 292.

123 ibid.

124 Bodansky (International Governance) (n 116) 6oo. 
not sufficiently contribute to legitimacy. It follows from this that if the procedural requirements (i.e. the proper acknowledgement of science) to satisfy input legitimacy are not sufficiently met, there is a risk that output legitimacy (i.e. the credibility of the substantive outcome; the sustainability of renewable energy replacing fossil-based energy) will also be lost. Therefore, the processes facilitating the transition must be closely informed by credible science and expertise to avoid inadequate, unsustainable outcomes in the clean energy transition and to ensure the procedural elements of energy democracy are satisfied.

Social acceptance of the renewable energy choices made to promote clean energy transition is also relevant to legitimacy in relation to forest bioenergy in the EU. Energy transformation affects society as a whole. ${ }^{125}$ Lack of social acceptance may be a 'constraining factor' in the shift to renewable energy. ${ }^{126}$ The case of $S a b o^{127}$ briefly discussed above signals that the public is no longer ready to accept regulatory choices characterized by a lack of transparency as to the weighing up of options in relation to the scientific knowledge available and the regulatory actions taken. On the other hand, strengthening democratic legitimacy can help promote greater levels of social acceptance. ${ }^{128}$ Burke and Stephens take the view that in order to improve outcomes and to achieve democratically legitimate consent, society as a whole needs to participate in and engage with the processes of energy transition. ${ }^{129}$ Scientific knowledge and experts must therefore address and convince the society as the principal actor in the clean energy transition. Moreover, the procedural justice elements discussed here highlight inclusion. Jenkins and others explain that procedural justice, in the context of energy justice, is more than just inclusion of relevant stakeholders - it is also about inclusion of knowledge and 'full information disclosure. ${ }^{130}$ The aspects of acceptance, inclusion and participation are all pertinent when discussing energy democracy.

Although the relationship between science and lawmaking is sometimes troubled and difficult, Bodansky explains that the absence of a simple

\footnotetext{
125 Szulecki (n 3$) 25$.

126 Rolf Wüstenhagen, Maarten Wolsink and Mary Jean Bürer, 'Social acceptance of renewable energy innovation: An introduction to the concept' (2007) 35 Energy Policy 26832691,2683 .

127 'EU Biomass Legal Case', available at <http://eubiomasscase.org/> accessed 23 June 2020.

128 Breffní Lennon, Niall P Dunphy and Estibaliz Sanvicente, 'Community acceptability and the energy transition: a citizens' perspective' (2019) 9(35) Energy, Sustainability and Society $1-18,3$.

129 Burke and Stephens (n 3) 37.

130 Jenkins and others (n 13) 178.
} 
relationship between science and action does not cancel out the importance of science. ${ }^{131}$ The failure of a regulatory framework to base its choices on best available science and expertise places its legitimacy at risk. ${ }^{132}$ This kind of conception is, for example, built into the precautionary principle, which relies on science to identify the risks that might justify a precautionary approach. ${ }^{133}$ Science can 'only' provide regulators with 'right and wrong (or at least better and worse) answers, ${ }^{\prime}{ }^{134}$ and the choice among the possible answers is sometimes a political one. ${ }^{135}$ This argument resonates rather well in the EU forest bioenergy context. Therefore, the dialogue between science and lawmaking needs to be inclusive, open and transparent to promote only sustainable regulatory choices. The idea of an inclusive dialogue also suits the context of energy democracy research that takes scientific and technical knowledge as belonging to 'a complex social, technical, political, cultural, and ecological system' that recognizes that expertise alone cannot guarantee an energy system transition. ${ }^{136}$ The energy democracy research agenda with which this chapter also engages thus builds a bridge 'between social and technical knowledge as well as between practice and research' to facilitate responsive energy governance. ${ }^{137}$

\section{$5 \quad$ Conclusion}

The chapter combined conceptual perspectives from the procedural justice and legitimacy discourses to identify and analyse the role of science in regulatory processes central to the sustainable energy transition. The demarcation between the roles of science and lawmaking was analysed through a practical regulatory context of sustainable forest bioenergy.

The role and relevance of science emerge within the regulatory processes relevant for energy democracy. Science should act as a key component in legitimizing the result of the regulatory processes. Although the legislator has sole legislative authority, the role of scientific knowledge as the prerequisite for sound lawmaking is important - especially when dealing with complex

\footnotetext{
131 Bodansky (International Governance) (n 116) 620-622.

132 ibid.

133 ibid.

134 ibid 621.

135 ibid.

136 Andrea M Feldpausch-Parker, Danielle Endres and Tarla Rai Peterson, 'Editorial: A Research Agenda for Energy Democracy' (2019) 4(53) Frontiers in Communication 1-8, 3. 137 ibid 7.
} 
systemic problems such as sustainability. Regulatory choices for the sustainable energy transition that are not adequately and transparently justified by science-based knowledge risk undermining faith in the legislator's choices concerning the facilitation of a truly sustainable energy transition. Moreover, such regulatory processes will fail to promote legitimacy.

The role of science in the regulatory frameworks relevant to energy transition bring forward a valuable interface for the study of energy democracy as a legal objective. The disconnect between science and lawmaking demonstrated by the practical regulatory example discussed above, the compromised sustainability and the legitimacy implications following from these challenges all embody different but substantive aspects of energy democracy. In other words, although there is a degree of obscurity as to the fundamental elements of the concept of energy democracy, it is possible to identify distinct features that contribute to achieving it. The role of science in regulatory processes relevant for the sustainable energy transition is key to the legitimization of the regulatory choices taken to facilitate the transition.

Finally, to an increasing extent, only regulatory choices that are supported by credible science are acceptable to the public. This is due to the ability of science to inform the legislator as to sustainable and science-based choices. This makes science an important participant in the regulatory processes concerning the achievement of a sustainable energy transition. Hence energy democracy requires both scientific and legal experts to be actively engaged in inclusive dialogue to be able to respond to the most daunting challenge of our time - sustainability. 